\title{
ANALISIS DAMPAK PERNIKAHAN USIA DINI DAN UPAYA PENCEGAHAN DI DESA JANAPRIA
}

Ira Indrianingsih, Fitri Nurafifah, Misnawati1, Deni Ramdani2, Syahrul Hamdani3, Yassir Amri4, Yusri Hadi Pratama5, Dianmita Ayu Putri6, Ni Luh Saras Putriyani7, Lusi Januartis

\author{
1Pendidikan Guru Sekolah Dasar, Fakultas Keguruan dan Ilmu Pendidikan \\ 2Teknik Pertanian, Fakultas Teknologi dan Agroindustri \\ ${ }_{3}$ Peternakan, Fakultas Peternakaan \\ 4Agribisnis, Fakultas Pertanian \\ 5Teknik Sipil, Fakultas Teknik \\ 6Teknik Informatika, Fakultas Teknik \\ 7 llmu dan Teknologi Pangan, Fakultas Teknologi Pangan dan Agroindustri \\ ${ }_{8}$ Pendidikan Fisika, Fakultas Keguruan dan IImu Pendidikan
}

\begin{abstract}
ABSTRAK. Pernikahan usia dini di kalangan remaja di Desa Janapria begitu memprihatinkan. Penelitian ini bertujuan untuk memaparkan salah satu permasalahan yang terdapat pada masyarakat di desa Janapria kecamatan Janapria Lombok Tengah Nusa Tenggara Barat, yakni tingginya angka pernikahan dini. Adapun batasan masalah penelitian ini mencakup dampak dari pernikahan dini dan upaya pencegahan. Penelitian ini termasuk ke dalam penelitian kualitatif deskriptif dengan jenis penelitian studi kasus. Adapun hasil yang diperoleh dari hasil wawancara dengan kepala desa Janapria serta masyarakat menyatakan bahwa banyak warga masyarakat yang menikah di bawah umur. Angka pernikahan dini paling tinggi di desa Janapria terdapat di 3 dusun yakni di dusun Menyer, di dusun Batu Bungus Utara dan di dusun Montong Kesene. Berbagai dampak yang terjadi sebagai akibat dari pernikahan dini bagi pasangan muda yakni meliputi bidang kesehatan bagi ibu dan bayi, ekonomi dan sosial, pendidikan, psikis, dan hukum. Adapun upaya pencegahan dengan melakukan sosialisasi pada remaja, sosialisasi pada masyarakat atau orang tua yang memiliki anak remaja, serta meningkatkan peran serta lembagalembaga resmi di Janapria untuk membantu dalam mencegah atau meninimalisir pernikahan usia dini.
\end{abstract}

Kata Kunci: Analisis, Pencegahan, Pernikahan Usia Dini

ABSTRACT. Early marriage among teenagers in the village of Janapria is very alarming. This study aims to describe one of the problems found in the community in the village of Janapria, Sub-district of Lombok, NTB, namely the high rate of early marriage. The limitation of this research problem covers the impact of early marriage and prevention efforts. This research is included in descriptive qualitative research with case study research type. The results obtained from interviews with the village head of Janapria and the community stated that many community members were married underage. The highest early marriage rates in the village of Janapria are in 3 hamlets namely in the village of Menyer, in the Batu Bungus Utara hamlet, and in the Montog kesene. 
The various impacts that occur as a result of early marriage for young couples include the fields of health for mothers and babies, economic and social, education, psychological and legal. As for prevention by conducting outreach to adolescents, socializing to the community or parents who have teenagers, as well as increasing the role of official institution Janapria to help prevent or minimalize eary marriage

Keyword: Early Marriage, Village, Impact, Effort

\section{PENDAHULUAN}

Seiring dengan perkembangan zaman di era modern saat ini, tidak juga melunturkan adat kebiasaan masyarakat di Lombok lebih khususnya pada masyarakat di desa Janapria. Janapria merupakan salah satu desa yang terdapat di kecamatan Janapra, Lombok Tengah. Janapria memiliki 23 lingkungan dengan jumlah penduduk yang padat dan dapat dikatakan cukup besar. Keadaan penduduk yang padat di Desa Janapria ini merupakan salah satu dampak dari adanya adat kebiasaan masyarakat di suku Sasak yaitu merariq qode' atau biasa disebut dengan pernikahan dini dan adapun keyakinan dari masyarakat bahwa banyak anak banyak rezeki.

Pernikahan usia dini adalah pernikahan di bawah usia yang seharusnya belum siap untuk melaksanakan pernikahan (Nukman, 2009). Pernikahan dini juga merupakan pernikahan yang dilakukan secara sah oleh seseorang laki-laki atau perempuan yang belum mempunyai persiapan dan kematangan sehingga dikawatirkan akan mengalami sejumlah resiko atau dampak yang besar. Dampak besar ini bahkan akan menjadi pengaruh dalam segi kesehatan saat melahirkan. (Nurhakhasanah, 2012). Sesuai dengan Undang-undang Nomor 1 Tahun 1974 tentang perkawinan, bahwa usia minimum nikah bagi laki-laki dan perempuan adalah 19 tahun.

Tidak bisa dipungkiri bahwa eksistensi pernikahan usia dini di kalangan masyarakat memiliki permasalahan yang urgensi dan perlu diatasi terlebih khusus di desa Janapria. Terdapat beberapa dampak yang terjadi sebagai akibat dari pernikahan usia dini di desa Janapria. Sehingga tujuan dari adanya penelitian ini adalah peneliti ingin memaparkan apa saja dampak dari pernikahan usia dini yang terdapat di desa Janapria dan upaya yang dapat dilakukan untuk mencegah pernikahan usia dini di desa Janapria.

Dari hasil wawancara dengan kepala desa dan masyarakat setempat, fenomena pernikahan dini di Desa Janapria secara tidak langsung memberikan dampak positif dan dampak negatif, hanya saja dampak negatif lebih mendominasi, sebagaimana penjelasan yang telah di paparkan sebelumnya terkait pengertian pernikahan usia dini memiliki dampak langsung 
terhadap risiko kesehatan fisik maupun mental ibu beserta sang bayi. Adapun dampak yang dialami pasangan yang menikah dini dari aspek positif antara lain mengaku lebih bertanggung jawab dan lebih mandiri dalam membangun rumah tangga sendiri. Adapun aspek negatif yang dialami pasangan antara lain pada kesehatan ibu dan bayi, pertengkaran antar pasangan lebih sering terjadi dikarenakan pola pikir pasangan yang masih belum cukup matang untuk menghadapi masalah rumah tangga yang dialami.

\section{ANALISIS PERMASALAHAN}

Angka pernikahan usia dini di provinsi Nusa Tenggara Barat (NTB) masih terbilang cukup tinggi. Pernikana dini masih menjadi pekerjaan berat bagi pemerintah Nusa Tenggara Barat (NTB) bahkan Wakil Gubernur NTB, H. Muh. Amin mengakui pernikahan dini di Nusa Tenggara Barat (NTB) sulit dikendalikan. Menurut data BKKBN, angka pernikahan dini pada tahun 2015 di NTB masih tingg. Rekor tertinggi dipegang oleh Kabupaten Lombok Timur dan Kabupaten Lombok Tengah dengan angka 67,15 persen dan 63,28 persen, disampaikan oleh kepala bidang keluarga sejahtera pemberdayaan keluarga, Baiq Nurhayati, kemajuan teknologi turut mempengaruhi angka ini. Di tambah seks pranikah dan penyalahgunaan narkoba.

Adapun hasil wawancara dengan kepala desa di Janapria, ibu staf di BKKBN, serta masyarakat setempat yang dapat disimpulkan bahwa terdapat banyak warga masyarakat di desa Janapria yang menikah di bawah umur atau yang biasa disebut dengan pernikahan dini hampir diseluruh dusun di desa Janapria, adapun masyarakat di sini menyatakan bahwa remaja di desa Janapria kalau tidak melanjutkan sekolah pasti akan menikah dan dari beberapa dusun di Janapria, yang pernah kami datangi juga memang terlihat beberapa warga yang sedang mengurus bayinya, yang kami amati tergolong masih belum dewasa atau cukup umur untuk melaksanakan tugas dan tanggung jawab sebagai orang tua.

\section{SOLUSI YANG DITAWARKAN}

Adapun upaya yang dilakukan untuk mencegah terjadinya pernikahan usia dini, antara lain sebagai berikut:

1. Mengadakan Sosialiasi Generasi Berencana (Genre) "Pendewasaan Usia Perkawinan" dan Pengenalan Universitas Mataram 


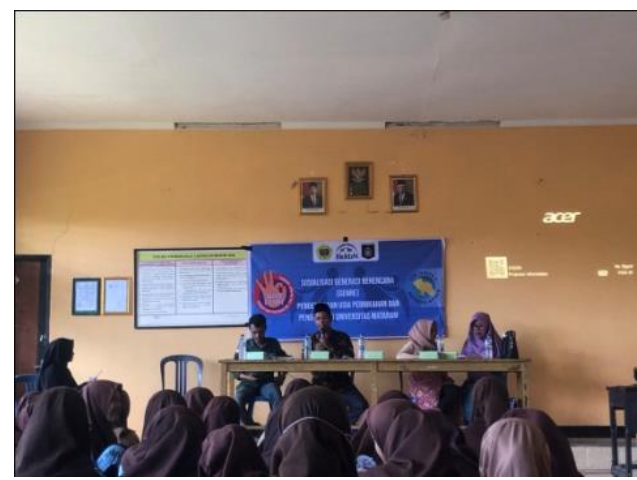

Gambar1. Sosialisasi Pendewasaan Usia Perkawianan dan Pengenalan Universitas Mataram di SMAN 1 Janapria)

Strategi pertama yang dilakukan yaitu sosialisasi di SMA atau target sasaran dalam sosialisasi pertama ini adalah kaum remaja. Tujuan sosialisasi pendewasaan usia perkawinan di kalangan remaja ini adalah untuk memberikan suatu pengertian dan kesadaran kepada remaja untuk mempersiapkan diri dalam merencanakan keluarga dan kesiapan mental, fisik, emosional, pendidikan, ekonomi serta merencanakan jumlah anak yang akan dilahirkan disamping jarak antar kelahirannya. Adapun tujuan dari sosialisasi pengenelana universitas mataram untuk memberi motivasi serta gambaran kepada remaja terkait dunia perkuliahan demi mencegah ataupun meminimalisir terjadinya pernikahan usia dini. Pendewasaan usia perkawinan juga berpengaruh besar terhadap kehamilan pertama terjadi pada usia yang cukup dewasa baik dari aspek kematangan reproduksi maupun aspek sosial spiritualnya. Pendewasaan usia perkawinan (PUP) erat kaitannya dengan masalah reproduksi, sebab perkawinan awal bagi remaja mengenal secara nyata tentang reproduksi, untuk itu suatu keniscayaan apabila sebelum memasuki masa perkawinan diharapkan mengenal "Perencanaan Keluarga" atau yang dikenal dengan istilah generasi berencana atau lebih dikenal dengan "Genre". Adapun dalam sosialisasi ini kami mendatangkan pemateri dari Kantor Urusan Agama (KUA) yaitu bapak Kamiludin, S.Ag untuk menyampaikan dampak pernikahan dini dan upaya pencegahannya dari sisi agama. Dan kami turut mengundang pemateri dari pihak puskesmas yaitu lbu Hj. Mutjayanah S. Keb dan Dr. Ririn Septemi untuk menyampaikan dampak pernikahan dini dan upaya pencegahannya dari sisi kesehatan.

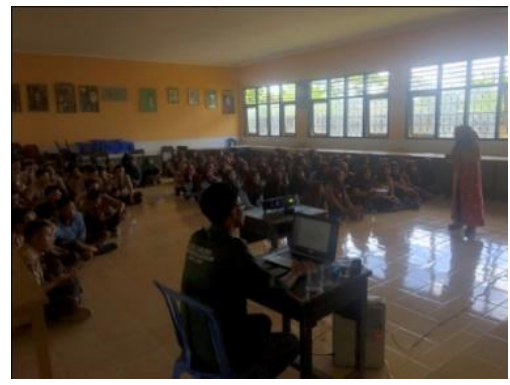

Gambar 2. Sosialisasi di SMAN 1 Janapri 


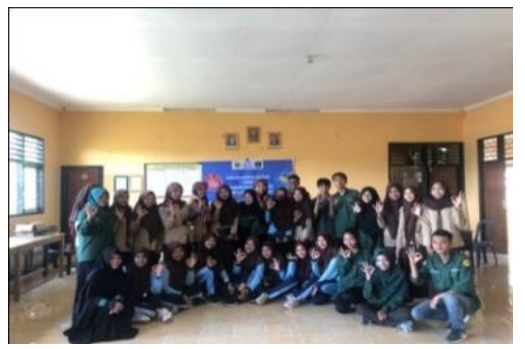

Gambar 3. Sosialisasi di SMAN 1 Janapri

2. Mengadakan Sosialiasi Generasi Berencana (Genre) dan Prilaku Hidup Bersih dan Sehat (PHBS)

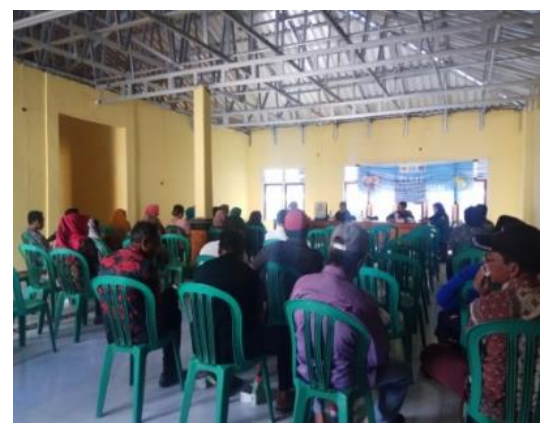

Gambar 4. Sosialisasi Generasi Berencana (Genre) dan Prilaku Hidup Bersih dan Sehat (PHBS) di Kantor Desa Janapria

Strategi kedua yang dilakukan yaitu sosialisasi kepada masyarakat atau target sasaran dalam sosialisasi kedua ini adalah keluarga yang memiliki anak remaja atau orang yang sudah menikah. Tujuan dari sosialisasi ini adalah untuk menyadarkan masyarakat mempertimbangkan usia pernikahan generasi muda. Generasi muda merupakan salah satu faktor penentu kemajuan bangsa Indonesia ke depan. Karena itu generasi muda harus lebih semangat dan benar-benar dipersiapkan dengan baik. Untuk itu perlu diadakannya sosialisasi Genre yang di peruntukkan bagi generasi muda dan orang tua yang memiliki anak remaja, agar mengetahui sejauh mana perencanaan kehidupan yang harus dipersiapkan kedepannya. Adapun pematerinya kami mengundang lbu Siti Zuriati dari pihak BKKBN untuk menyampaikan materi tentang kesehatan reproduksi dan bahaya pernikahan dini dan Ibu Sumiati dari pihak puskesmas menyampaikan materi terkait prilaku hidup bersih dan sehat. Dalam sosialisasi ini orang tua dihimbau untuk membantu pemerintah dalam mencegah terjadinya pernikahan usia dini. Dalam kesempatan tersebut, pihak BKKBN juga menyampaikan bahwa keluarga adalah kunci utama dalam melindungi anak dari permasalahan anak usia dini khususnya yang berkaitan dengan terjadinya pernikahan dini. 


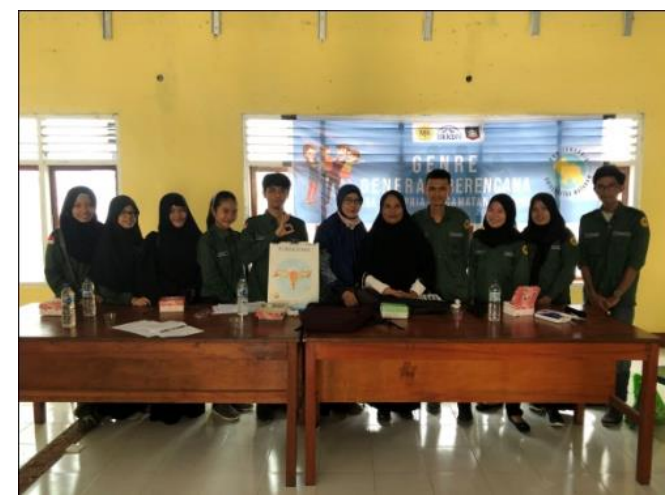

Gambar 5. Foto Bersama Pemateri dalam Sosialisasi di Kantor Desa

3. Meningkatkan Peranan Pihak ke-3 (Kepala Desa, Kepala Puskesmas, Kepala Kantor Urusan Agama, dan dari pihak BKKBN)

Strategi yang ketiga dengan meningkatkan peranan beberapa lembaga setempat, adapun kami mendatangi beberapa pihak yang dapat membantu atau berperan aktif dalam masyarakat untuk dapat memberi arahan terkait permasalahan pernikahan usia dini. Karena pihak ke-3 di sini mempunyai pengaruh terhadap kualitas dan kepuasan masyarakat, terhadap pelayanan yang diberikan, selain itu juga dengan turunnya pihak ke-3 secara langsung dapat membantu masyarakat dalam memahami dampak dari pernikahan dini serta cara mencegah pernikahan dini. Adapun lembaga-lembaga yang kami datangi yaitu pertama kepala desa sebagai aparat desa didbutuhkan untuk memberikan arahan kepada masyarakat untuk dapat mencegah terjadinya pernikahan dini. Begitu pula kepada pihak dari BKKBN, dari pihak puskesmas, dari pihak kantor urusan agama, masyarakat, dan lainnya. Melakukan penyuluhan maupun sosialisasi untuk mengurangi angka pernikahan dini yang terjadi. Pendidikan masyarakat mengenai dampak-dampak maupun resiko yang dihasilkan pernikahan dini juga perlu digiatkan untuk menumbuhkan kesadaran masyarakat akan pentingnya rencana sebelum melakukan pernikahan demi terwujudnya program keluarga berencana. 


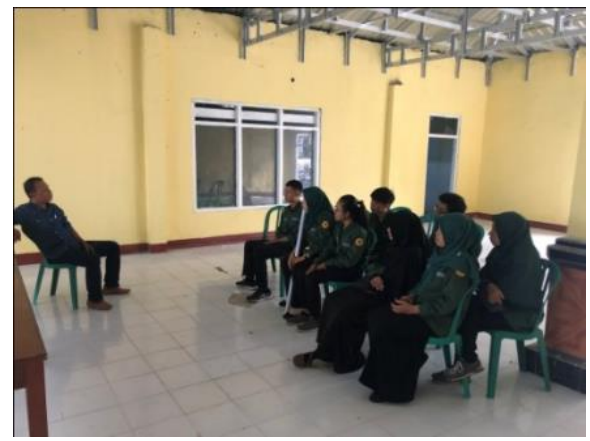

Gambar 6. Diskusi Bersama Bapak Kepala Desa Janapria di Kantor Desa

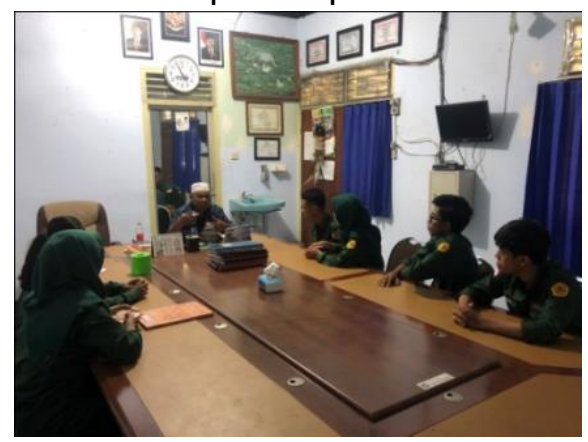

Gambar 7. Diskusi Bersama Bapak Kepala Puskesmas di Puskesmas Janapria

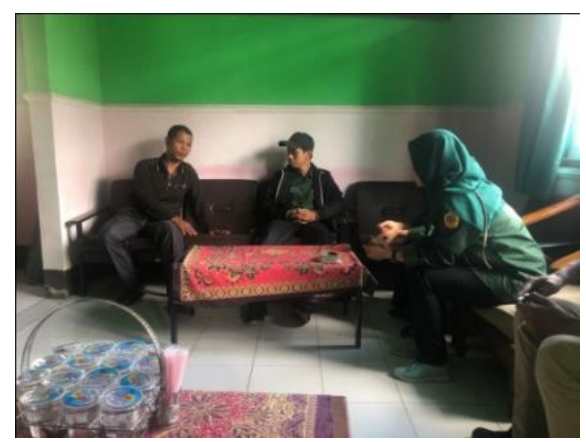

Gambar 8. Diskusi Bersama Bapak Kepala KUA di KUA Janapria

\section{HASIL DAN PEMBAHASAN \\ Dampak Pernikahan Usia Dini}

Adapun dampak terjadinya pernikahan usia dini yang kami dapatkan dari hasil wawancara di lapangan yang dapat kami rangkum antara lain, sebagai berikut:

1. Kesehatan

Dari segi kesehatan pasangan muda yang melakukan pernikahan dini akan beresiko mengalami masalah kesehatan reproduksi seperti kanker leher Rahim dan trauma fisik pada 
organ intim. Dengan kata lain, Rahim anak remaja cenderung tidak dapat menahan calon bayi yang seharusnya bertahan didalam kandungan selama kurang lebih 9 bulan. Jika dipaksa akan menyebabkan persalinan premature karena lahir sebelum usia 38 minggu, pecahnya ketuban, keguguran, mudah terkena infeksi hingga anemia kehamilan (kekurangan zat besi) selain itu memiliki kecenderungan yang tinggi untuk melahirkan anak yang stunting, resiko kesehatan ibu dan bayi lebih tinggi seperti tekanan darah tinggi , dan kemungkian terburuk kematian dan janin pendarahan saat melahirkan disebabkan karena otot Rahim yang terlalu lemah menyebabkan pendarahan relatif lebih sulit berhenti.

\section{Ekonomi dan sosial}

Secara umum remaja yang menikah usia dini sering kali mengalami masalah ekonomi yang menjadi salah satu sumber ketidakharmonisan rumah tangga atau keluarga. Pasangan usia muda belum mampu dibebani suatu perkerjaan yang memerlukan ketrampilan fisik untuk mendatangkan penghasilan baginya dan mencukupi keluarganya. Sehingga sering kali ditemukan pasangan usia muda yang masih tinggal bersama orang tuanya. Faktor ekonomi merupakan salah satu yang berperan dalam mewujudkan kesejahteraan dan kebahagiaan rumah tangga.

\section{Pendidikan}

Dampak dari aspek pendidikan adalah individu atau pelaku yang melakukan pernikahan dini cenderung akan putus sekolah setelah melakukan pernikahan. Hal ini disebabkan karena perasaan malu yang dimiliki oleh pelaku menikah muda, terhadap teman-teman sebayanya yang masih menikmati bangku sekolah, selain itu peraturan denda yang diberlakukan oleh sekolah bagi siswanya yang melakukan pernikahan dini juga menjadi salah satu alasan siswa tersebut untuk memutuskan berhenti sekolah. Akibatnya lama sekolah mereka yang semestinya panjang menjadi lebih singkat. Hal tersebut karena pelaku harus membagi pikirannya dalam banyak hal seperti mengurus suami ataupun sebaliknya dan tentunya harus mengurus anak.

4. Psikis

Dampak dari segi Psikis yang dialami pasangan yang melakukan pernikahan dini antara lain adanya ketidak siapan secara mental, trauma dan krisis percaya diri, kemudian emosi tidak berkembang dengan matang sehingga akan berpotensi mengalami kegagalan dalam membangun keluarga. Selain itu, pernikahan usia dini juga menyebabkan gangguan kognitif, seperti tidak berani mengambil keputusan, kesulitan memecahkan masalah dan terganggunya 
memori. Tidak hanya itu, kondisi emosiaonal yang masih labil ketika paska melahirkan pasangan muda akan mengalami (baby blues), rentan mengalami stress ataupun depresi karena tuntuan sebagai orang tua muda.

5. Hukum

Perkawinan yang sah menurut Pasal 2 UU Perkawinan, apabila dilakukan menurut hukum masing-masing agamanya dan kepercayaannya dan dicatat menurut peraturan perundangundangan yang berlaku.

Menurut Kementrian Urusan Agama (KUA) bahwa batasan umur di dalam ketentuan Pasal 7 ayat (1) UU Perkawinan disebutkan bahwa "Perkawinan hanya diizinkan jika pihak pria sudah mencapai umur 19 (sembilan belas) tahun dan pihak wanita sudah mencapai umur 16 (enam belas) tahun." Adapun perubahan norma dalam pasal 7 ini menjangkau batas usia untuk melakukan perkawinan, perbaikan norma menjangkau dengan menaikkan batas minimal umur perkawinan bagi wanita. Dalam hal ini batas minimal bagi wanita dipersamakan dengan batas minimal umur perkawinan bagi pria, yaitu 19 (sembilan belas) tahun.

Berdasarkan ketentuan pasal tersebut, maka yang dimaksud dengan menikah muda atau pernikahan dini (perkawinan di bawah umur) adalah perkawinan yang dilakukan sebelum usia 19 tahun bagi laki-laki dan sebelum usia 19 tahun bagi perempuan. Hal ini menyebabkan pasangan yang menikah sebelum usia yang disebutkan diatas tidak dapat mengurus akta menikah dan membuat Kartu Kelurga mereka sebagai keluarga baru sehingga pasangan tersebut tidak dapat disahkan secara hukum.

\section{KESIMPULAN}

Terdapat beberapa dampak yang terjadi akibat adanya pernikahan usia dini antara lain dampak dibidang perekonomian keluarga, hasil pernikahan dini sering kali mengalami masalah ekonomi. Dampak dari segi kesehatan pasangan muda yang melakukan pernikahan dini akan berisiko mengalami masalah kesehatan reproduksi serta resiko kesehatan ibu dan bayi lebih tinggi. Dampak dari bidang pendidikan yaitu putus sekolah setelah melakukan pernikahan. Dampak pada bidang psikis sering terjadinya pertengkaran rumah tangga akibat ketidak siapan mental pasangan untuk menjadi rumah tangga dan yang terakhir dampak di bidang hukum pasangan suami istri dibawah umur tidak memiliki akta nikah dan KK.

Sehingga penulis menyarankan perlunya peran aktif keluarga untuk membentuk pola pikir anak dan memberikan pengetahuan mengenai pernikahan dini dan seks sejak usia dini agar 
terhindar dari pernikahan dini. Setelah itu perlunya peran dari pihak kantor desa, puskesmas, kantor urusan agama dan kantor BKBBN dalam peningkatan pengetahuan remaja akan risiko pernikahan usia dini, baik berupa penyuluhan maupun sosialisasi serta publikasi melalui media informasi. Partisipasi masyarakat juga diperlukan untuk meyukseskan kegiatan yang digalakan oleh puskesmas, kepala desa, kantor urusan agama dan BKKBN untuk mengurangi angka pernikahan dini yang terjadi. Pendidikan masyarakat mengenai dampak-dampak maupun resiko yang dihasilkan pernikahan dini juga perlu digiatkan untuk menumbuhkan kesadaran masyarakat akan pentingnya rencana sebelum melakukan pernikahan demi terwujudnya program keluarga berencana.

\section{UCAPAN TERIMAKASIH}

Terimakasih kami ucapkan kepada semua pihak yang telah membantu kami, kepada Bapak Kepala desa Janapria, Bapak Kepala Puskesmas Janapria, Bapak Kepala KUA, Ibu Staff BKKBN dan masyarakat setempst yang telah memberikan kami fasilitas dan informasi untuk menggali data, sehingga kami dapat menyelesaikan artikel kami terkait pernikahan usia dini di Desa Janapria.

\section{REFERENSI}

Anonim. 2016. Pentingnya Pendewasaan Usia Perkawinan. Diakses di http://jatim.bkkbn.go.id/pentingnyapendewasaan-usia-perkawinan/ pada tanggal 27 Januari 2020 pukul 09:02 WITA.

Julijanto, Muhammad. 2015. Dampak Pernikahan Dini dan Problematika Hukumnya. Jurnal Pendidikan Ilmu Sosial 25 (1) hal. 62-72

Moleong. 2005. Metodologi Penelitian Kualitatif. Bandung: PT Remaja Rosdakarya

Suarantb. 2017. Pernikahan Dini di NTB Sulit Dibendung. Diakses di https:/www.google.com/amp/s/www.suarantb.com/ntb/2017/07/24217/Pernikahan.Dini.di.NTB.S ulit.Dibendung/ pada tanggal 27 Januari 2020 pukul 07:48 WITA

Sugiyono. 2018. Metode Penelitian Pendidikan (Pendekatan Kuantitatif, Kualitatif dan R\&D). Bandung: Alfabeta. 
